\title{
Did major fractures in continental crust control orientation of the Knipovich Ridge-Lena Trough segment of the plate margin?
}

\author{
M. D. MAX AND Y. OHTA
}

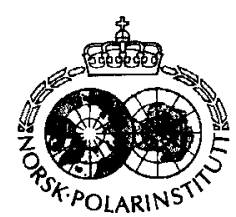

\begin{abstract}
Max, M. D. \& Ohta, Y. 1988: Did major fractures in continental crust control orientation of the Knipovich Ridge-Lena Trough segment of the plate margin? Polar Research 6, 85-93.

Orientation of the complex Knipovich-Lena spreading/transform system closely follows the secondary shear and extensional orientations that existed within adjacent continental crust prior to rifting. Major dextral faults and shear zones within continental crust appear to have affected both the lower crust and upper mantle during extension and to have caused the localization of the early transform rift system.
\end{abstract}

M. D. Max, Naval Research Laboratory, Acoustics Division, Washington D.C. 20375, U.S.A.; Y. Ohta, Norsk Polarinstitutt, P.O. Box 158, 1330 Oslo lufthavn, Norway; June 1987 (revised December 1987).

One of the more dramatic offsets of a spreading ridge/transform system occurs in the NorwegianGreenland Sea between the Senja-Greenland and Yermak Fracture Zones. This offset is now comprised of oceanic crust in a rift separating sheared margins (Eldholm et al. 1987). The Knipovich Ridge-Lena Trough (Fig. 1), which forms the offset plate margin between the Mohns and NansenGakkel Ridges (Ohta 1982; Vogt 1986a, b) appears to be composed of segments that depart by up to $20^{\circ}$ from a purely orthogonal system. The transforms lie at moderate angles to the continental margins, rather than at higher angles that are more characteristic of the Arctic-Atlantic ridge system. As transforms track the orientation of crustal extension, this ridge segment would appear to be anomalous with respect to rifting because extension is neither parallel to the bounding continental margins nor is it orthogonal.

The offset transforms are seen in bathymetry (Perry et al. 1980) only in the northern end of the Lena-Knipovich ridge, but Vogt $(1986 a, b)$ has suggested from magnetic data that transform offsets of the plate margin in the Knipovich Ridge early in the ridge history were more pronounced than they are now. This suggests that the Knipovich Ridge is coalescing into a straighter course with time. Our thesis of extensive early structural control of the plate margin involving an imprint of dextral strain paths onto the early formed oceanic crust is consistent with the concept that as the margin matures, it is less likely to reflect an early structural control; hence the apparent contradiction between the early magnetic striping and the current bathymetry can be resolved. An alternate model for establishment of this N-NNW ridge involving two phases of opening (Eldholm et al. 1987) also shows non-orthogonal ridge/ transform orientations in the early opening phase, but introduces significant space problems whose resolution within an orthogonal ridge/transform system is not clear.

In this paper we argue that the large scale geometry of the anomalous transform/rift system suggests a close relationship between transpressional strain in the continental crust prior to rifting and the orientation of the purely 'oceanic' structures.

\section{Major transverse deep structures in Atlantic border continental crust}

Kjøde et al. (1978) and Sundvor \& Eldholm (1979) show that the Trollfjorden-Komagelv Fault (Fig. 2) and parallel faults in northernmost Norway and faults in the southwestern part of 


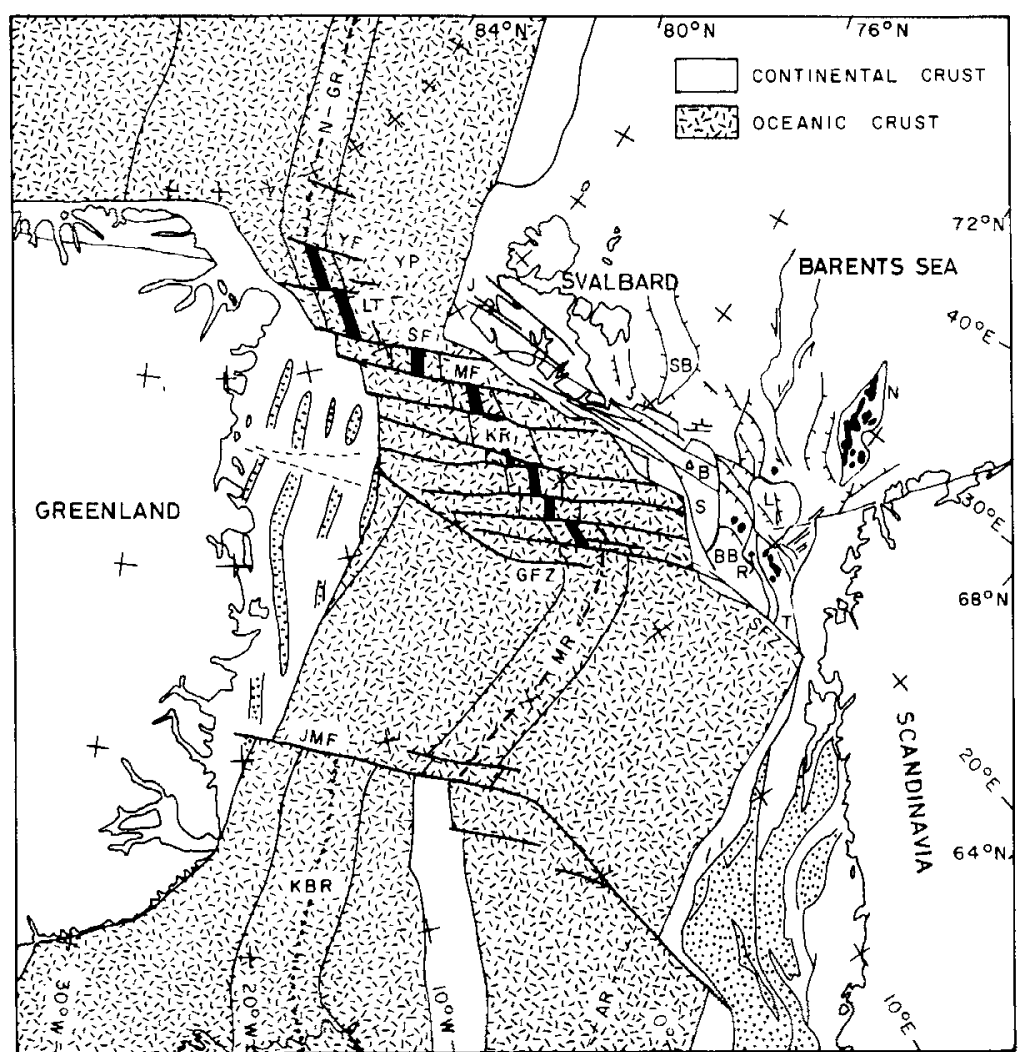

Fig. 1. Present disposition of structural trends in continental and oceanic crust in the North Atlantic region. Transforms near continental crust and the shape of the Greenland margin are speculative, but follow Vogt $(1986 a, b)$. Dotted areas are sedimentary basins within the continental crust in the Greenland and Norwegian margin apart from the Barents Sea. Solid, evaporite diapirs at or near the seabed in the southern Barents Sea. AR, Aegir Ridge; B, Bjørnøya; BB, Bjørnøya Basin; GFZ, Greenland Fracture Zone; J, Devonian Boundary Faults; JMF, Jan Mayen Fracture Zone; KBR, Kolbeinsey Ridge; KR, Knipovich Ridge; L, Loppa High; LT, Lena Trough; MF, Molloy Fracture; MR, Mohns Ridge; $\mathrm{N}$, Nordkapp Basin; N-GR, Nansen-Gakkel Ridge; R, Senja Ridge; S, Stappen High; SB, Sentralbanken High; SF, Spitsbergen Fracture; SFZ, Senja Fracture Zone; T, Tromsø Basin; YF, Yermak Fracture; YP, Yermak Plateau. Solid along the Knipovich Ridge is oceanic crust younger than $10 \mathrm{my}$ according to Vogt (1986a, b).
Spitsbergen were wrench faults during the opening of Iapetus in latest Precambrian to Cambrian times. Movement was dextral in relation to Baltica, but sinistral within Svalbard. Harland \& Gayer (1972) regarded the Trollfjorden-Komagelv fault as a suture between Baltica and the 'Barents shelf terrane'. To the east (Fig. 4). the fault can be followed across the Arkhangelsk inlet and into Russia (Roberts \& Gale 1978) along the southern margin of the Late Precambrian (Baikalian) Kanin-Timian orogenic belt (Siedlecka 1975). The Barents Sea Group, along the northern part of the Varanger peninsula, may have been transported from a position close to present west Spitsbergen. Spitsbergen would have had to have been to the west and north Varanger to the east of Iapetus opening (Kjøde et al. 1978).

A line of faulting within the Caledonian nappes across Finnmark and out onto the Continental shelf (Gee et al. 1985) indicates the course of the Trollfjorden-Komagelv Fault (Fig. 3). Basement faults have apparently propagated upward into the Caledonian thrust sheets. Gudlaugsson et al. (1987) show faults along this line to the middle of the Hammerfest Basin. Faleide et al. (1984) also show WNW faults within the Hammerfest Basin lying along a NW continuation of the Trollfjorden-Komagelv Fault line. These trans-basinal faults were active during the early Tertiary (Riis et al. 1985).

In western Svalbard and the continental margin in the vicinity of Bjørnøya (Bear Island), major Upper Palaeozoic faults, which were repeatedly reactivated in mid-Jurassic and late Cretaceous times, have been followed to the SSE (Rønnevik \& Jacobsen 1984). These faults swung to the east in the shelf of late Caledonian times and pass toward the western end of the TrollfjordenKomagelv Fault zone (Fig. 4). Detailed fault correlation along the strike is difficult, but Rønnevik \& Jacobsen (1984) show a persistent NW-SE fault trend. In the late Devonian, faults emanating from southern Svalbard curved to the SE and $\mathrm{E}$ through the Stappen High and into the Bjørnøya 
Basin. In the mid-Permian, faults emanating from southern Svalbard died out in the Bjørnøya Basin. In the mid-Jurassic, probable sinistral movements along the north side of the Loppa High truncated and deflected NW-SE trending faults in the Bjørnøya Basin. In the top Lower Cretaceous, NWSE faults existed across the Bjørnøya Basin and east to Bjørnøya. No faults connecting the westward continuation of the Trollfjorden-Komagelv Fault and the SE continuation of the Hornsund Fault system were traced across the Loppa High by Faleide et al. (1984).

An arcuate, major gravity linear can be traced from off the SW coast of Svalbard, where it is about coincident with the continental margin,

Fig. 2. General geological framework in the supercontinent showing the relationships of major fault lines and the probable positioning of the westward continuation of the TrollfjordenKomagely Fault (after Ziegler 1978). F, Finnmark; GGF, Great Glen Fault; RF, Reach Fault. Caledonian orogen in the North Atlantic region patterned; southern Caledonian front not depicted. Note the extent of the transverse fault zones in the North Atlantic region. CGFZ, Cedabucto-Gibraltar Fault Zone; LBFZ, Labrador-Biscay Fault Zone; TKFZ, Trollfjorden-Komagelv Fault Zone; TL, Tornquist Line.

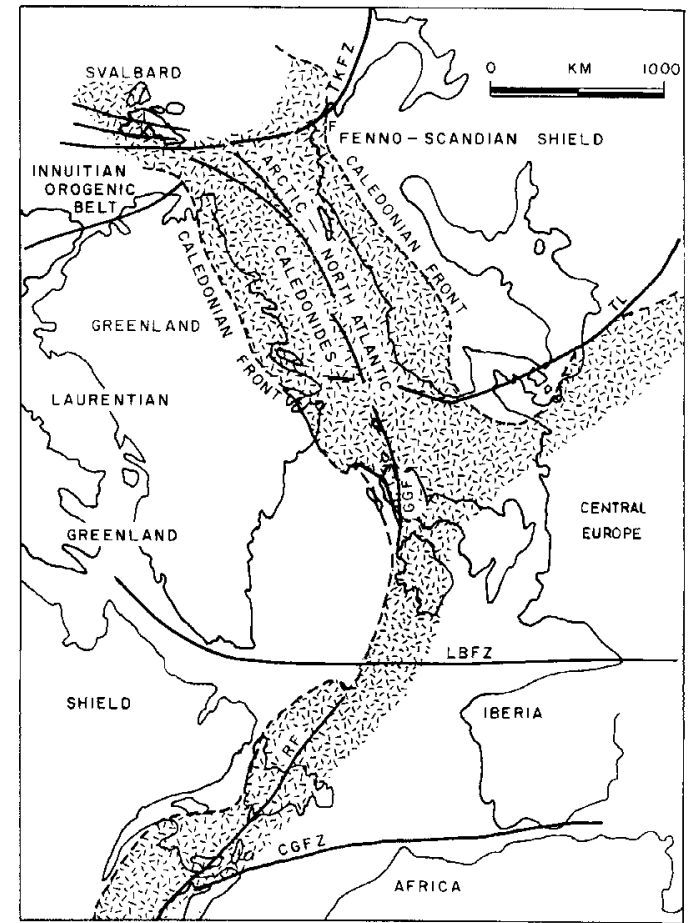

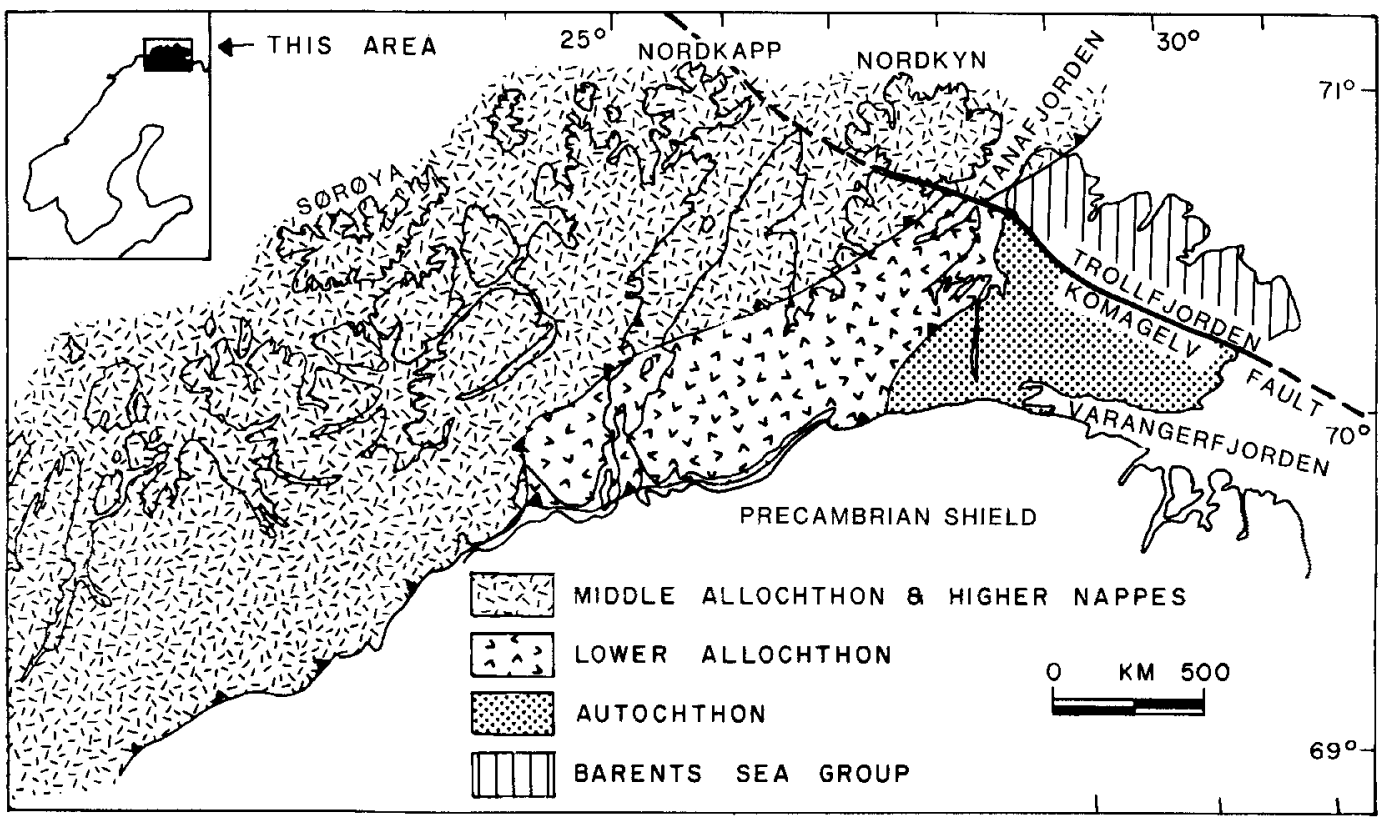

Fig. 3. General geology of the Finnmark area, northernmost Norway showing the high structural level Caledonian Middle Allochthon (nappe front) truncating the westward end of the Trollfjorden-Komagelv Fault and itself being displaced along the fault trace (after Gee et al. 1985). Lower and Middle (and higher) Allochthons are Caledonian in age. Toothed line indicates major thrust fronts. Autochthon includes Precambrian shield and sedimentary cover over shield. 


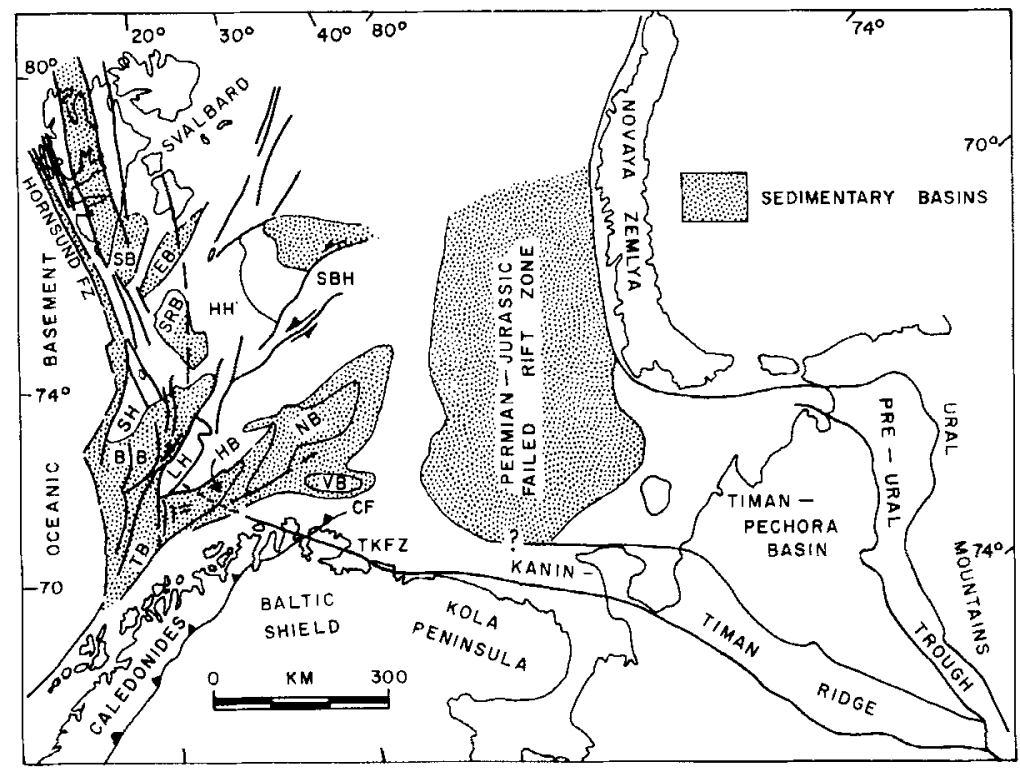

Fig. 4. General geology of the southern and western part of the Barents Sea. Eastward continuation of the TrollfjordenKomagelv Fault as a structural front carries into the western Ural Mountains forming a feature that is at least $1200 \mathrm{~km}$ long. Western continuation is along the complex continental margin and into the nexus of faults that is associated with the Hornsund Fault Zone. CF, Caledonian Front; TKFZ, Trollfjorden-Komagelv Fault Zone. Basins: BB, Bjørnøya Basin; EB, Edgeøya Basin; HB, Hammerfest Basin; NB, Nordkapp Basin; SB, Storfjorden Basin; SRB, Sørkapp Basin; TB, Troms $\emptyset$ Basin; VB, Varanger Basin. Highs: HH, Hopen High; LH, Loppa High; SBH, Sentralbanken High; SH, Stappen High. Arrows on margin of the Sentralbanken High and the Bjørnøya Basin show wrench fault sense. Heavy lines are faults. southeast toward the Norwegian coast (Riis et al. 1985). It passes as a smooth, undisrupted feature northeast of Bjørnøya through a region of faults stepping down to the NE into the Sørkapp Basin, across the Bjørnøya Basin and through the Loppa High. With a single, small sinistral offset coincident with the margin of Sentralbanken, the linear passes across the Hammerfest Basin coincident with trans-basinal faults, and into the Trollfjorden-Komagelv Fault trace. We regard this gravity linear as marking the subjacent course of a deep, major fault feature.

Faults on a NE-SW trend controlled the elongate boundaries of the Hammerfest, NordkappBjørnøya and Storfjorden basins and the Stappen, Sentralbanken and Loppa Highs; this trend is one of the three major orientations of basement faults in the northwestern margin of the Barents Shelf (Ohta 1982, 1983). The fault along the SE margin of the Loppa High penetrates the Moho (Gudlaugsson et al. 1987). The Troms 6 -Finnmark Fault Zone along NW Norway marks a division between the little-faulted craton of mainland Scandinavia and the Barents Shelf, which suffered extensive faulting. Sinistral faulting on NE-SW trending faults along the Sentralbanken High probably passes along the Loppa High margins. These shears cross our projected westward con- tinuation of the Trollfjorden-Komagelv Fault trend and could explain the local lack of rejuvenation.

Wrench movement of the Hornsund Fault Zone (Sundvor \& Eldholm 1979) was driven by dextral transpression (Lepvrier \& Geyssant 1984; Vogt $1986 \mathrm{a}, \mathrm{b})$; the fault became the plate boundary in anomaly 23 times ( 52 million years B.P.). The Norway-Svalbard continental margin and its analogue in north Greenland constitute one of the best documented oblique sheared margins in the Arctic-Atlantic rift system (Eldholm et al. 1987). The Hornsund Fault now forms the margin between continental crust of the Svalbard Platform and oceanic crust (e.g. McWhae 1986).

During early Tertiary transpression, northeastward directed thrusting strongly affected the western half of Spitsbergen. These thrusts may now be either truncated at depth within the Hornsund Fault Zone or form a flower structure splay to the steep-dipping Hornsund Fault (Lowell 1972; McWhae 1986). Steep faults in western Svalbard cut shallow faults or thrusts. Lepvrier \& Geyssant $(1984,1985)$ separate strike slip and thrust movement into separate and distinct episodes based on superposition of fault striations. Transient transtensional zones, however, commonly form in transpressional systems and 
younger faults commonly cut across major faults of the same strain system (Dickenson 1983).

Basin-dipping, shallow faults commonly root in subjacent extensional faults. Gudlaugsson et al. (1987) show low angle, seaward dipping seismic events in middle and lower crust beneath basins. These may be structural relics of the early Tertiary transpression or they may be new structures, albeit with a partially reactivated origin, that formed during the extensional event leading to rifting.

Gee (1972) suggested that some strike-slip displacements on longitudinal faults in north-central Spitsbergen occurred in Silurian times, prior to or during deposition of Old Red Sandstone. This strike-slip occurred coeval with the culmination of late Silurian-early Devonian/end-Caledonian thrusting in Norway. Ziegler's (1978) reconstruction takes the Great Glen Fault of Britain along the western shelf margin of Norway and between Greenland and Svalbard, following the reconstruction of Kjøde et al. (1978) rather than directly into Svalbard (Harland 1978, 1985). Lamar et al. (1986) argue that while some wrench movement may have occurred along the Billefjorden Fault Zone before the mid-Devonian, there could not have been the 200 to $1000 \mathrm{~km}$ of late Devonian movement proposed by Harland \& Gayer (1972), Harland (1978) and Harland et al. (1984).

Some lower Mesozoic basins in and near Svalbard have faulted margins, which root in deep faults in the metamorphic basement. Formation of these basins dates back to late SilurianDevonian times with pronounced subsidence during the Carboniferous (Gjelberg \& Steel 1979; Steel \& Worsley 1984). Basin formation in late Palaeozoic times was probably a response to the dextral E-W or NW-SE shear in the Laurasian supercontinent (Arthaud \& Matte 1977; Matte 1986). These basins deepened and filled with Mesozoic and Tertiary strata.

\section{Major continental crust structures and their effect on oceanic lithosphere}

Over much of the North Atlantic region, continental crust structural patterns are regarded as having been subsequently expressed in the position and orientation of ridge/transform systems in oceanic crust. Cherkis et al. (1973) related the position of the Gibbs Fracture Zone between Newfoundland and Ireland to major structures in the continental crust. Max \& Lefort (1984) also regarded the existence of the Gibbs Fracture Zone and continental fault zones as being genetically related. On a smaller scale, Lefort \& Max (1984) and Max (1987) regarded transform faults in the Porcupine Seabight on the Irish shelf as prolongations of steep-dipping dextral faults. Once orthogonal tensional fault/transfer fault systems are established, it would seem that the pattern can be transferred to at least the early oceanic crust within the rift. Transform faults in the Nansen-Gakkel Ridge of the Arctic Ocean line up with some of the north-trending longitudinal faults in northern Svalbard (Fig. 1), and there may be a direct connection between these longitudinal faults and apparent oceanic crust continuations (Ohta 1983).

Major structures of the continental crust are known to penetrate the Moho (Blundell et al. 1985) of the British shelf. Deep-reaching steep longitudinal faults in western Spitsbergen, which control a Devonian and younger graben passing across the western entrance to Isfjorden, show up to $5 \mathrm{~km}$ displacement of the Moho (Sellevoll et al. 1982). Deep, low-angle faults south of Edgeøya (Gudlaugsson et al. 1987) imaged on deep seismic lines, suggest Caledonian subduction or compressional fault features.

Transfer of a structural pattern from continental to oceanic crust must involve a relationship between structure and the development of deep seated magmas. Shear would introduce a highly localized ductility contrast in the lithosphere that would most likely affect the underlying mantle by introducing local anisotropy. Steep-dipping faults and shear zones commonly are exploited by igneous intrusion. Water, which is commonly pumped within fault systems, can be expected in deep faults and shear zones; it would have a significant effect on metamorphism, strain rate adaptation, and the development of magma. A line of fault-related magma chambers along an extensional zone, which was localized by downward propagation of crustal structure, could well mature into axial magma chambers in a rift. The early chambers in the zone of mantle upwelling might well continue to be exploited because of the established ductility and other physical-chemical gradients.

Magma chamber alignment adjacent in the continental margin to the northwest of Spitsbergen 
appears to have been related to steep-dipping deep faults passing north from the Devonian Graben. These faults in Svalbard are associated with some volcanic activity and a few dykes occur in the Devonian basin. Sellevoll et al. (1982), however, show a c. $3 \mathrm{~km}$ transitional zone Moho only under the Central Spitsbergen Tertiary basin that is characteristic of mobilized lower crust or igneous underplating (Hauser et al. 1987). The northern prolongation of this fault, in the middle of the Yermak Plateau, is coincident with a positive magnetic anomaly that suggests submarine volcanics. Amundsen et al. (1987) show several Tertiary-Quaternary volcanic centers aligned along the western margin of the graben. Both upper mantle ultrabasic and lower continental crustal high-temperature granulite xenoliths in the volcanics demonstrate subsided continental crust. The Yermak Plateau itself is considered, on a larger scale, to be a product of a local hot spot (Feden et al. 1979). The Morris-Jessup Plateau to the NE of northern Greenland was once part of the Yermak Plateau, but it has been rifted and separated by spreading of the NansenGakkel Ridge. The position of the early hot spot, high volumes of pre-rift volcanics and a major change in ridge/transform geometry are related to the position of older steep-dipping deep faults that penetrate the Moho in northwestern Svalbard.

In both the Wernicke and delamination models of basin forming related to lower crustal extension (Wernicke \& Burchfel 1982), detachment faults or shear surfaces propagate from the surface through the Moho and into the upper mantle (Lister et al. 1986). Magma derived from the mantle is likely to be selectively generated on the upthrown or footwall of the deep-propagating shear. In contrast, the pure-shear symmetrical model that thins the lower crust while suprajacent upper crust responds in a brittle manner and forms sedimentary basins, symmetrically raises the Moho in the region of greatest thinning (McKenzie 1978). In this idealized model of basin formation, the only possibility for a fault system seen on the surface to propagate through the Moho is by rejuvenation of steep shear zones.

Detachment faults form in rifted continental crust at passive margins. Characteristically, steepdipping transfer faults lie about normal to the surface trace of the detachment faults, in which they root (Gibbs 1984), and they commonly form in the half-graben complex overlying detachment faults (Lister et al. 1986). These transfer faults are shear surfaces that develop orthogonally and allow adjacent half-graben segments to develop independently. They perform a similar function to transform faults in oceanic crust in separating crustal segments. In a newly forming passive margin, both steep-dipping shears that are longitudinal to rifts and new transfer faults that are orthogonal to the rift trend, offer a path of propagation into oceanic lithosphere. If a strongly defined chain of early magma chambers were established under structural control, its presence might well fix transform/ridge orientations of a new plate margin.

\section{Strain and the structural pattern in the continental crust}

Dextral strain will set up a regular pattern of secondary shear and tensional structures related to the orientation and degree of compression within the primary major shearing path. Fig. $5 \mathrm{a}$ shows the orientation structures with increasing compressional strain. As the strain increases, the secondary shear elements rotate toward the primary plane. In extreme cases, for instance in mylonites, primary, synthetic and antithetic shears all lie statistically in the same plane with divergence only near strain inhomogeneities. The plane of extension coincidentally rotates toward an orthogonal position with respect to the primary major shears (Fig. 5a, state 3). In extreme cases rotation may be greater than $90^{\circ}$.

Long axes of the sedimentary basins in the northern part of the North Sea, the west Norwegian-Greenland Sea and the western part of the Barents Sea continental shelves have a common $\mathrm{N}-\mathrm{S}$ trend. This is parallel to basins in the Irish Shelf that formed in response to a dextral wrench on northwest trending shear zones (Lefort \& Max 1984). A subsequent extensional event associated with the development of the North Atlantic northward from the Labrador-Biscay Fault Zone formed rifts that lay along a more clockwise trend, and cross-cuts this older extensional basin trend (Fig. 5b).

Widespread late and post-Hercynian dextral movement along major faults that were transverse to the proto-north Atlantic took place from the southern Appalachians to the Finnmark-Svalbard region (Ziegler 1978). These major dextral shears formed during Hercynian tectonism and reac- 

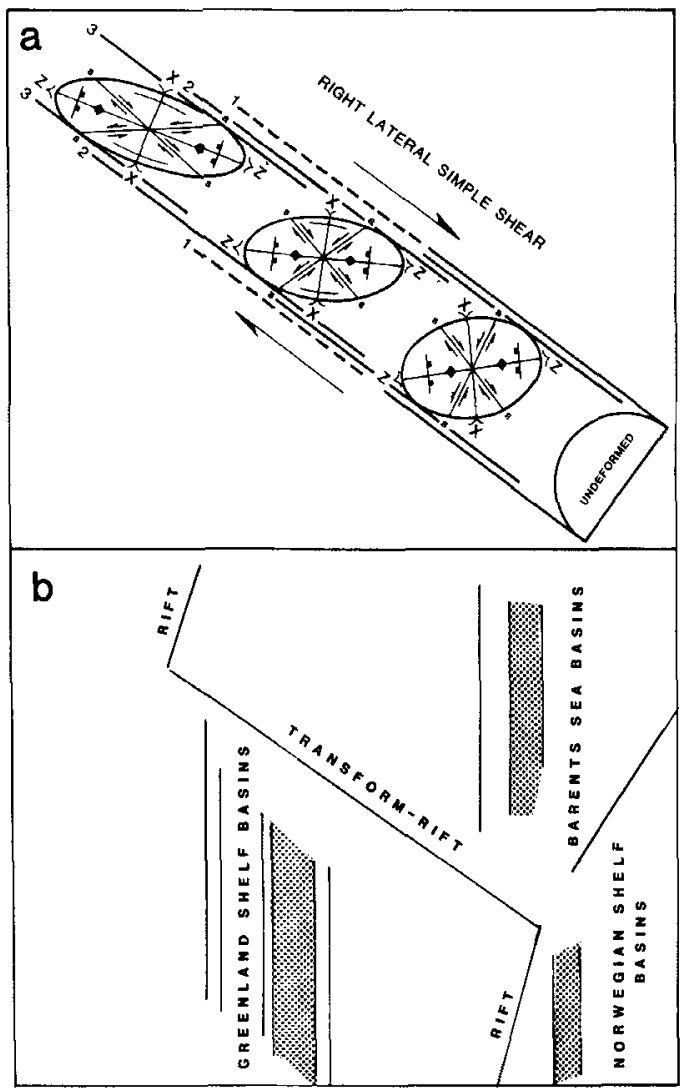

Fig. 5. a. Relationship of transpressional dextral shearing strain. $1-3$, deformation and rotation of the deformational ellipsoid with inereasing strain. The consequent rotation and change are in angular relationships between the secondary and the primary shear paths. Primary shear oriented to rough parallelism with the present Hornsund FZ (north vertical). $X$, axis of principal compressive strain; $Z$, axis of minimum compression ( $Z Y$ is the plane of flattening); $s$, synthetic shear; a, antithetic shear.

b. Disposition of the older sedimentary basins (patterned) after Vogt $(1986 \mathrm{a}, \mathrm{b})$ and the generalized line of the Tertiary rift and wrench fault system (heavy line).

tivation of already existing major structural breaks in the earth's crust (Matte 1986). Although the early extensional and the rifting events might have been formed under other influences, their geometry and timing suggest that establishment of the rifting trend could have been a natural consequence of increased transpressional dextral strain within the northwest trending dextral fault system. With increasing compression across the primary shear trend, the axial plane of the direction of extension within this shear couple would have moved to a more clockwise position (Fig. 5a).
Movement along the Trollfjorden-Komagelv/ Hornsund Fault Zone (HTKFZ) compensated spreading to the south of the Greenland-Senja FZ. The nexus of faults that parallels the SW coast of Spitsbergen roughly parallels the continental margin. The Tromsø and Hammerfest Basins, that lie on the continuation of the HTKFZ, appear to form a separate structural area. These basins are more narrow and offset from their eastern prolongations. The northern terminations of the Bjørnøya, Stappen and Loppa Highs (Fig. 1) are also parallel, and close to, this line. The breadth of the shear zone in the continental crust may be picked out by the location of the profusion of

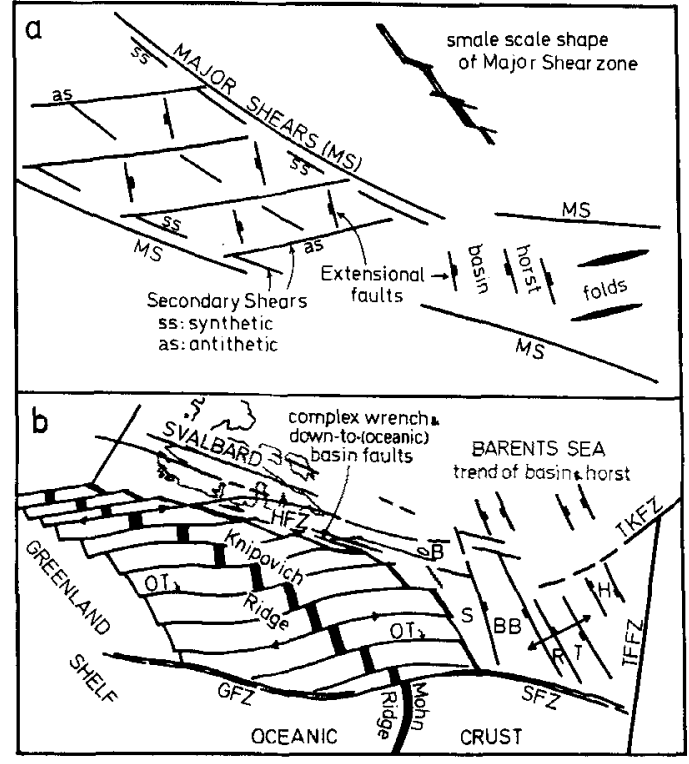

Fig. 6. a. Strain paths in the proto-rift continental crust in high compressional strain transpression; AS, antithetic shear path; MS, major shear path; SS, synthetic shear path. Pattern of major and secondary shears and faults would be repeated at a variety of scales.

b. Diagrammatic relationships between the orientation of the Knipovich Ridge system and the Barents Sea continental margin. Transforms offset spreading ridge creating oceanic crust. Note that the direction of offset on the transforms coincides with the sense of movement on the antithetic strain path related to the sheared continental margins. The surface trace of an individual fault in a closely related set (HFZ) should not be expected to have acted as the major shear throughout the history of shearing and basin formation. GFZ, Greenland Fault Zone; HFZ, Hornsund Fault Zone; OT, oceanic transform; SFZ, Senja Fault Zone; R, Senja Ridge; TKFZ, Trollfjorden-Komagelv Fault Zone; TFFZ, Tromsø-Finnmark Fault Zone; arrows indicate the direction of extension. The Hornsund Fault Zone segment is a complex area of tight, elongate Tertiary sedimentary basins, faults, and basement highs. 
transforms that helps to isolate the Knipovich Ridge from the Mohns and Nansen-Gakkel Ridges between the Spitsbergen-Molloy FZ and the Greenland-Senja FZ (Fig. 1). The southern end of the Knipovich Ridge passes into the Senja Fault Zone and the northern margin passes into the northern part of the Hornsund Fault Zone (Fig. 6). Splays of this fault set may penetrate into Spitsbergen as the Kongsfjorden FZ and other faults (Ohta 1982, 1983).

The orientation of the spreading centers of the Knipovich Ridge segment lies about parallel to the antithetic strain path orientation in the prerift continental crust (Fig. 5a). The apparent absence of synthetic fault structural elements associated with the continental margins to the Knipovich oceanic segment indicates that compression in the transpressive framework was intense. This indication that compression was important, is also indicated by the antithetictransform trend, which lies at a relatively low angle to the primary shear along the continental margin. In addition, there is a nearly orthogonal relationship of the axis of the direction of extension and the inherently extensional ridge axis that is at a high angle to the primary major shear (Fig. 6b).

\section{Conclusions}

The southern margin to late Precambrian deformation of the Barents Sea Group in North Norway is an important structural line that can be followed along reactivated fault lines westward beneath Caledonian nappes, the North Greenland fold belts (Pearyan and Ellesmerian orogenic zones) and Devonian sedimentary basins on the continental shelf. This line passes into the vicinity of the southeastern end of the Hornsund Fault Zone at a low angle to the south of Bjørnøya. Faults in Svalbard and on the continental shelf that parallel the Hornsund Fault Zone west of Svalbard pass to the east to about the intersection of the Hammerfest Basin and the Barents Sea Group's southern structural front.

The apparent continuity of major, steepdipping deep faults that may have their origins in the Late Precambrian, in an area that has suffered subsequent extensional tectonics and rifting during formation of the Iapetus and North Atlantic Oceans and mobile belt during Caledonian tectonism, implies that the later events reactivated the older features without annealing or seriously displacing them. Alternatively, annealed areas could have redeveloped these trends by propagation from unannealed regions. As the Caledonian deformation on both the Greenland and Norwegian margins is dominated by thrust tectonics, the zone of deep-seated Caledonian deformation, if any remains, would be confined to a narrow zone in the outer continental shelves. Although faults on a Caledonian trend pass weil into the Barents Sea, it is possible that Iapetus also propagated along western Svalbard, utilizing one of the older Late Precambrian faults.

Dextral strain in this region appears to have exploited the orientation of these older structures during the northward migration of the North Atlantic spreading ridge system from the Greenland Sea to the Eurasian basin of the Arctic Ocean. The non-orthogonal relationship of the ridge segments and transforms on the extended Knipovich Ridge probably reflects strain vectors inherited from Tertiary and older rifting of continental crust.

Acknowledgements. - Many thanks to P. Vogt for discussions on the geology and geophysics of this area and for access to his collection of data.

\section{References}

Amundsen, H. E. F., Griffin, W. L., O'Reilly, S. Y. 1987: The lower crust and upper mantle beneath northwestern Spitsbergen: evidence from xenoliths and geophysics. Tectonophysics $139,169-185$

Arthaud, F. \& Matte, P. 1977: Late Paleozoic strike-slip faulting in southern Europe and northern Africa: Result of a rightlateral shear zone between the Appalachians and the Urals. Geological Society of America Bulletin 88, 1305-1320.

Blundell, D. J., Hurich, C. A. \& Smithson, S. B. 1985: A model for the MOIST seismic reflection profile, N Scotland. Geological Society of London Journal 142, 245-258.

Cherkis, N. Z., Fleming, H. S. \& Massingill, J. V. 1973: Is the Gibbs Fracture Zone a westward projection of the Hercynian Front into North America? Nature 245, 113-115.

Dickenson, W. R. 1983: Cretaceous sinistral strike slip along Nacimiento Fault in coastal California. American Association of Petroleum Geologists Bulletin 67, 624-645.

Eldholm, O., Faleide, J. I. \& Myhre, A. M. 1987: Continent ocean transition at the western Barents Sea/Svalbard con tinental margin. Geology 15, 1118-1122.

Faleide, J. I., Gudlaugsson, S. T. \& Jacquart, G. 1984: Evolution of the western Barents Sea. Marine and Petroleum Geology 1, 123-150.

Feden, R. H., Vogt, P. R. \& Fleming, H. S. 1979: Magnetic and bathymetric evidence for the 'Yermak Hot Spot' northwest of Svalbard in the Arctic Basin. Earth and Planetary Science Letters 44, 18-38.

Gee, D. G. 1972: Late Caledonian (Haakonian) movements in northern Spitsbergen. Norsk Polarinstitutt Ärbok 1970, 92 101. 
Gee, D. G., Kumpulainen, R., Roberts, D., Stephens, M. B., Thon, A. \& Zachrisson, E. 1985: Scandinavian Caledonides Tectonostratographic Map $(1: 2,000,000)$. In Gee, D. G. \& Sturt, B. A. (eds.): The Caledonide Orogen-Scandinavia and Related Areas. John Wiley \& Sons, London.

Gibbs, A. D. 1984: Structural evolution of extensional basin margins. Geological Society of London Journal 141, 609-620.

Gjelberg, J. \& Steel, R. 1979: Middle Caboniferous sedimentation in relation to tectonic, climatic and sea level changes on Bjørnøya and Spitsbergen. North Sea Symposium, Tromsø. NSS/27.

Gudlaugsson, S. T., Faleide, J. I., Fanavoll, S. \& Johansen, B. 1987: Deep seismic reflection profiles across the western Barents Sea. Geophysical Journal of the Royal Astronomical Society. Special Issue of Deep Seismics, 273-278.

Harland, W. B. 1978: The Caledonides of Svalbard. Pp. 3-11 in Caledonian-Appalachian Orogen of the North Atlantic Region. Geological Survey of Canada Paper 78-13.

Harland, W. B. 1985: Caledonide Svalbard. Pp. 999-1016 in Gee, D. G. \& Sturt, B. A. (eds.): The Caledonide OrogenScandinavia and related areas. John Wiley \& Sons, London.

Harland, W. B., Cutbill, J. C., Friend, P. F., Gobbett, D. J., Holliday, D. W., Maton, P. I., Parker, J. R. \& Wallis, R. H. 1984: The Billefjorden Fault Zone, Spitsbergen. Norsk Polarinst. Skr, $161.72 \mathrm{pp}$.

Harland, W. B. \& Gayer, R. A. 1972: The Arctic Caledonides and earlier oceans. Geological Magazine 109, 289-314.

Hauser, E., Potter, C., Hauge, T., Burgess, S., Burtch, S., Mutschler, J., Allmendinger, R., Brown, L., Kaufman, S. \& Oliver, J. 1987: Crustal structure of eastern Nevada from COCORP deep seismic reflection data. Geological Society of America Bulletin 99, 833-844.

Kjøde, J., Storetvedt, K. M., Roberts, D. \& Gidskehaug, A. 1978: Palaeomagnetic evidence for large-scale dextral movement along the Trollfjord-Komagelv Fault, Finnmark, North Norway. Physics of the Earth and Planetary Interiors $16,132-144$.

Lamar, D. L., Reed, W. E. \& Douglass, D. N. 1986: Billefjorden Fault zone, Spitsbergen; Is it part of a major Late Devonian transform? Geological Society of America Bulletin 97, 1083-1088.

Lefort, J. P. \& Max, M. D. 1984: Development of the Porcupine Seabight: use of magnetic data to show the direct relationship between early oceanic and continental structures. Geological Society of London Journal 141, 663-674.

Lepvrier, C. \& Geyssant, J. 1984: Tectonique cassant et champs de contrainte tertiaires de long de la marge en coulissement du Spitsberg: Corrélations avec les méchanismes d'ouverture de la mer de Norvège-Groënland. Ann. Soc. Géol. Nord III, 333-344.

Lepvrier, C. \& Geyssant, J. 1985: L'évolution structurale de la marge occidentale du Spitsberg: coulissement et rifting tertiaires. Bulletin Société géologique de France 87(1), 115125.

Lister, G. S., Etheridge, M. A. \& Symonds, P. A. 1986: Detachment faulting and the evolution of passive continental margins. Geology 14, 246-250.

Lowell, J. D. 1972: Spitsbergen Tertiary Orogenic Belt and the Spitsbergen Fracture Zone. Geological Society of America Bulletin 83, 3091-3102.

Matte, P. 1986: La chaine varisque parmi les chaines paléozoïques péri atlantiques, modele d'évolution et position des grands blocs continentaux au Permo-Carbonifére. Bulletin Société géologique de France 8, 9-24.

Max, M. D. 1987: The three phase development of the Por- cupine Seabight Basin formation and the sedimentary pattern. Journal of Petroleum Geology 10, 59-72.

Max, M. D. \& Lefort, J. P. 1984: Does the Variscan front in Ireland follow a dextral shear zone? In Hutton, D. H. W. \& Sanderson, D. J. (eds.): Variscan Tectonics of the North American region. Geological Society of London Special Publication 14.

McKenzie, D. P. 1978: Some remarks on the development of sedimentary basins. Earth and Planetary Science Letters 40 , 25-32.

McWhae, J. R. 1986: Tectonic history of northern Alaska, Canadian Arctic and Spitsbergen regions since Early Cretaceous. American Association of Petroleum Geologists Bulletin 70, 430-450.

Ohta, Y. 1982: Morpho-tectonic studies around Svalbard and the northernmost Atlantic. Pp. 415-429 in Ashton, F. E. \& Balkwill, H. R. (eds.): Arctic Geology and Geophysics. Canadian Sociery of Petroleum Geologists Memoir 8.

Ohta, Y. 1983: Caledonian fractures in Svalbard. Pp. 339350 in Gabrielsen, R. H., Ramberg, I. B., Roberts, D. \& Steinlein, O. A. (eds.): Proceedings of the 4th International Conference of Basement Tectonics, 1981.

Perry, R. K., Fleming, H. S., Cherkis, N. Z., Feden, R. H. \& Vogt, P. R. 1980: Bathymetry of the Norwegian-Greenland and western Barents Sea. Naval Research Laboratory, Acoustics Division, 1:2,333,230 map.

Riis, F., Vollset, J. \& Sand, M. 1985: Tectonic development of the Western Margin of the Barents Sea and adjacent areas. NPD contribution $22.14 \mathrm{pp}$.

Roberts, D. \& Gale, G. H. 1978: Caledonian-Appalachian and Iapetus Ocean. Pp. 255-342 in Tarling, D. H. (ed.): The Evolution of the Earth's Crust. Academic Press, London.

Rønnevik, H. \& Jacobsen, H. P. 1984: Structural highs and basins in the western Barents Sea. Pp. 19-32 in Petroleum Geology of the North European Margin. Norwegian Petroleum Society (Graham \& Trotman, London).

Sellevoll, M. A., Duda, S., Komber, J., Pajchel, J., Guterch, A. \& Perchuc, E. 1982: Seismic Crustal Studies on Spitsbergen 1978. Seismological Observatory Report, University of Bergen. 62 pp.

Siedlecka, A. 1975: Late Precambrian stratigraphy and structure of the North-Eastern Margin of the Fennoscandian Shield (East Finnmark - Timian region). Norges geologiske Undersøkelser 316, 313-348.

Steel, R. J. \& Worsley, D. 1984: Svalbard's post-Caledonian strata - an atlas of sedimentational patterns and palaeogeographic evolution. Pp. 109-135 in Spencer, S. M. et al. (eds.): Petroleum Geology of the North European Margin. Norwegian Petroleum Society (Graham \& Trotman, London).

Sundvor, E. \& Eldholm, O. 1979: The western and northern margin off Svalbard. Tectonophysics 59, 239-250.

Vogt, P. R. 1986a: Geophysical and geochemical signatures and plate tectonics. Pp. 413-662 in Hurdle, B. G. (ed.): The Nordic Seas. Springer-Verlag, New York.

Vogt, P. R. 1986b: Magnetic anomalies and crustal magnetization. Pp. 229-256, Plate 8B in Vogt, P. R. \& Tucholke, B. E. (eds.): The Geology of North America, Vol. M, The Western North Atlantic Region. Geological Society of America.

Wernicke, B. \& Burchfel, B. C. 1982: Modes of extensional tectonics. Journal of Structural Geology 4, 105-115.

Ziegler, P. A. 1978: North-western Europe: tectonics and basin development. Geologie en Mijnbouw 57, 589-626. 
